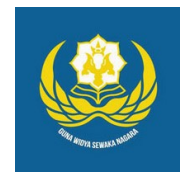

Jurnal Analogi Hukum

Journal Homepage: https://ejournal.warmadewa.ac.id/index.php/analogihukum

\title{
Pembinaan Terhadap Narapidana Lanjut Usia di Lapas Kelas II A Denpasar
}

\author{
I Wayan Diva Adi Pradipta*, I Ketut Sukadana dan Ni Made Sukaryati Karma
}

Fakultas Hukum, Universitas Warmadewa, Denpasar-Bali, Indonesia

*divaadipradipta@gmail.com

\begin{abstract}
How To Cite:
Pradipta, I. W. D. A., Sukadana, I. K., \& Karma, N. M. S. (2020). Pembinaan Terhadap Narapidana Lanjut Usia di Lapas Kelas II A Denpasar. Jurnal Analogi Hukum. 2 (2). 209-214. Doi: https://doi.org/10.22225/ah.2.2.1890.209-214

Abstract-Correctional Institutions are one of the institutions that enforce the law in terms of guidance carried out on inmates where all types of rules carried out in Penitentiary Institutions are regulated in Law Number 12 of 1995 concerning correctional facilities. The formulation of the problem that the authors put forward is, (1) What is the process of foster elderly prisoners in Class IIA Denpasar Prisons according to Law No. 12 of 1995 concerning Corrections. (2) What are the efforts to resolve the obstacles faced in conducting guidance to elderly prisoners in Class IIA Denpasar Prison. This study uses empirical methods by collecting data through interviews in the field. This research was conducted at the Class II A Denpasar Penitentiary located in the Kerobokan area of Badung Regency. The results of the research found that in the Penitentiary that accommodated 1684 inmates with the class of 7 child inmates, 1663 adult prisoners and 14 elderly prisoners had given special treatment to elderly prisoners because elderly prisoners did not have the ability which is sufficient to carry out all the coaching activities that should have been carried out, but there are no specific regulations that regulate in detail regarding this matter. Giving special treatment and establishing rules regarding procedures for fostering elderly prisoners is a mandatory step in order to create a process of fostering elderly prisoners who are in accordance with the conditions of the elderly prisoners themselves.
\end{abstract}

Keywords: Correctional Institution, Old Age, Development

Abstrak - Lembaga Pemasyarakatan merupakan salah satu lembaga yang menegakkan hukum dalam hal pembinaan yang dilakukan terhadap para narapidana dimana segala jenis aturan yang dilakukan di dalam Lembaga Pemasyarakatan diatur dalam Undang-Undang Nomor 12 Tahun 1995 tentang pemasyarakatan. Adapun rumusan masalah yang penulis kemukakan yaitu, (1) Bagaimana proses pembinaan narapidana lanjut usia di Lapas Kelas IIA Denpasar menurut UU No.12 Tahun 1995 Tentang Pemasyarakatan. (2) Apakah upaya penyelesaian terhadap kendala yang dihadapi dalam melakukan pembinaan pada narapidana lanjut usia di Lapas Kelas IIA Denpasar. Penelitian ini menggunakan metode empiris dengan mengumpulkan data melalui wawancara di lapangan. Penelitian ini dilakukan di Lembaga Pemasyarakatan Kelas II A Denpasar yang terletak di daerah Kerobokan Kabupaten Badung. Hasil penelitian di lapangan didapat bahwa di Lembaga Pemasyarakatan yang menampung 1684 narapidana dengan klasifikasi 7 orang narapidana anak, 1663 orang narapidana dewasa serta 14 orang narapidana lansia ini telah memberikan perlakuan khusus kepada narapidana yang sudah lanjut usia karena para narapidana yang sudah lanjut usia tidak memiliki kemampuan yang cukup untuk melakukan segala kegiatan pembinaan yang seharusnya dilakukan, namun tidak ada peraturan khusus yang mengatur secara detail terkait hal tersebut. Memberikan perlakuan khusus dan membentuk aturan mengenai tata cara pembinaan terhadap narapidana yang sudah lanjut usia merupakan langkah yang wajib dilakukan agar terciptanya proses pembinaan terhadap para narapidana lanjut usia yang sesuai dengan kondisi narapidana lanjut usia itu sendiri.

Kata Kunci: Lembaga Pemasyarakatan, Lansia, Pembinaan.

\section{Pendahuluan}

Hukum adalah suatu sistem yang dibuat manusia untuk membatasi tingkah laku manusia agar tingkah laku manusia dapat terkontrol, hukum adalah aspek terpenting dalam pelaksanaan atas rangkaian kekuasaan kelembagaan. Hukum mempunyai tugas untuk menjamin adanya kepastian hukum dalam masyarakat. Oleh karena itu setiap masyarakat

Jurnal Analogi Hukum, Volume 2, Nomor 2, 2020. CC-BY-SA 4.o License 
berhak untuk mendapat pembelaan didepan hukum sehingga dapat di artikan bahwa hukum adalah peraturan atau ketentuan-ketentuan tertulis maupun tidak tertulis yang mengatur kehidupan masyarakat dan menyediakan sanksi bagi pelanggarnya. Tujuan hukum mempunyai sifat universal seperti ketertiban, ketentraman, kedamaian, kesejahteraan dan kebahagiaan dalam tata kehidupan bermasyarakat.

Dalam menjaga ketenangan dan ketertiban masyarakat inilah di Indonesia diterapkan juga sistem pemidanaan berupa kurungan/ pidana penjara di lembaga permasyarakatan (Lapas) bagi para pelanggar peraturan ataupun para narapidana yang terbukti melakukan tindak pidana. Lapas sebagai sebuah bagian yang berperan aktif dalam proses pembinaan terhadap narapidana, mempunyai tugas dan wewenang yang sangat kompleks, mengingat setiap hari nya terjadi banyak sekali kasus pidana yang terjadi dan para pelaku nya akan mendapat hukuman dan pembinaan dibalik tembok Lapas itu sendiri.

Namun dalam pelaksanaan pembinaan itu sendiri, perlu diingat bahwa Hak Asasi Manusia (HAM) adalah hak yang melekat di dalam diri pribadi individu, dan hak ini merupakan yang paling mendasar bagi setiap individu untuk berdiri dan hidup secara merdeka dalam komunitas masyarakat. Bangunan-bangunan dasar HAM yang melekat dalam episentrum otoritas individu yang merdeka merupakan bawaan semenjak lahir sehingga tidak dapat digugat dengan banalitas pragmatisme kepentingan kekuasaan, ambisi dan hasrat. Dengan dan atas nama apapun, bahwa dasardasar kemanusiaan yang intim harus dilindungi, dipelihara dan tidak dibiarkan berada sama sekali dalam ruang-ruang sosial yang mengalienasinya (Tumpa, 2009).

Sifat hakiki dan kodrati HAM yang melekat pada diri setiap orang tidak dapat di cabut atau dihapuskan oleh siapapun termasuk penguasa negara. Menghapus dan mencabut HAM sama artinya menghilangkan eksistensi manusia sebagai ciptaan Tuhan Yang Maha Esa. Maka dari itu perlu adanya peninjauan mengenai hak-hak asasi dari narapidana itu sendiri yang mana hak asasi itu memang masih bisa mereka peroleh walau sedang berada dalam tahap pembinaan di Lapas. Seperti yang di ketahui, bahwa para tahanan di Lembaga Permasyarakatan dihukum sesuai dengan kejahatan yang dilakukan oleh para pelaku, ada yang dihukum 3 tahun masa kurungan, 5 tahun, 10 tahun hingga seumur hidup.

Dari sekian banyak narapidana yang mendapatkan hukuman, tentu saja pasti ada narapidana yang sudah lanjut usia (lansia) namun harus melewati masa tua mereka di penjara akibat dari perbuatannya. Para narapidana lanjut usia ini yang perlu mendapat perhatian khusus mengingat tenaga dan juga keadaan mereka yang tak lagi sekuat dulu ketika mereka masih muda, karena walaupun posisi mereka disini adalah sebagai narapidana tetapi juga harus tetap mengingat bahwa mereka adalah manusia ciptaan Tuhan yang meempunyai HAM dan perlu mendapat perlakuan khusus narapidana yang sudah lanjut usia.

Pada penelitian sebelumnya, (Beliferdo, Darmadi, \& Tjatrayasa, 2013) menemukan bentuk pembinaan terhadap narapidana lanjut usia pada Lembaga Pemasyarakatan Kelas II B di Kabupaten Karangasem, antara lain program pendidikan, seperti pendidikan mental kerohanian, pendidikan praktis atau keterampilan dan pendidikan umum. Program pekerjaan atau keterampilan, dengan memberikan pendidikan keterampilan seperti menjarit, membuat anyaman dan lain-lain. Program keamanan/tata tertib, melalui mengadakan hubungan yang baik antara narapidana dengan petugas LP. Program kesehatan.perawatan/olahraga, seperti: senam pagi, kesenian musik, jalan santai dan program kemasyarakatan, seperti dengan mengadakan hubungan dengan masyrakat luar sehingga napi tidak canggung lagi terjun di masyarakat. Namun hal sebaliknya ditemukan dalam penelitian (Barus \& Biafri, 2020) yang mengungkapkan bahwa banyak narapidana lanjut usia yang dalam pembinaannya di samakan dengan narapidana pada umumnya, pelayanan yang belum terlihat untuk lansia seperti pelayanan rohani dan pelayanan fisiknya (kesehatan) dan membutuhkan pembinaan kemandirian yang khusus kerena dapat kita lihat dari kondisi fisik yang sudah tidak sebaik narapidana pada umumnya sehingga narapidana lansia harus mendapat pembinaan yang sesuai Undang-undangnya.

Berdasarkan latar belakang yang diuraikan diatas, penelitian ini bertujuan untuk menganalisis proses pembinaan narapidana lanjut usia di Lapas Kelas IIA Denpasar Menurut Undang-Undang No. 12 Tahun 1995 tentang Pemasyarakatan dan upaya penyelesaian terhadap kendala yang dihadapi dalam melakukan pembinaan kepada narapidana lanjut usia di Lapas Kelas IIA Denpasar

\section{Metode}


Metode penulisan yang digunakan dalam penelitian ini adalah dengan metode penelitian hukum empiris. yaitu penelitian yang berfokus pada perilaku masyarakat hukum, dan penelitian ini memerlukan data primer sebagai data utama disamping data sekunder (bahan hukum) (Efendi \& Ibrahim, 2016).

Pendekatan masalah yang digunakan dalam penulisan proposal penelitian skripsi ini adalah sosiologi hukum. Dimana pendekatan sosiologi hukum dilakukan dengan cara pendekatan studi hukum di masyarakat, yang secara empiris menguji dan merumuskan interaksi antara hukum, lembaga hukum, lembaga non-hukum dan faktor sosial (Yusuf, 2014).

Sumber data dalam penelitian ini adalah sumber data dimana data diperoleh dari hasil penelitian empiris, yaitu penelitian yang dilakukan langsung didalam masyarakat yakni peneliti melaksanakan kegiatan penelitian langsung di dalam Lembaga Pemasyarakatan kelas IIA Denpasar terkait proses pembinaan yang dilakukan terhadap para narapidana yang sudah tergolong lanjut usia.

Data yang di dapat oleh peneliti berupa data primer dan data sekunder dimana Data Primer yaitu data asli atau dasar yang diperoleh langsung dari sumbernya. Pengambilan data ini diperoleh dengan cara meminta keterangan dan penjelasan dari pihak yang terkait dengan permasalahan yang diteliti. Dalam hal ini adalah data yang berasal dari lokasi penelitian yang diperoleh di Lapas Kelas IIA Denpasar.

Data sekunder yaitu data yang diperoleh dari penelitian kepustakaan (library research) guna mendapatkan landasan teoritis berupa pendapat dan tulisan para ahli. Cara yang dipakai dalam penelitian keputusan adalah membaca buku, literatur, artikel dan tulisantulisan ilmiah lainnya. Teknik pengumpulan data secara primer yakni dengan menggunakan 2 cara yaitu obervasi (pengamatan) dan juga interview (wawancara). Sedangkan teknik pengumpulan data sekunder yakni dengan membaca dan meneliti hasil pemikiran yang telah dituangkan dalam literatur-literatur atau buku-buku yang dikeluarkan oleh para ahli.

\section{Hasil dan Pembahasan}

\section{Proses Pelaksanaan Pembinaan Narapidana di Lembaga Pemasyarakatan Kelas II A Denpasar}

Lembaga Pemasyarakatan sebagai sebuah badan yang berdiri dibawah naungan Direktorat
Jenderal Pemasyarakatan Kementrian Hukum dan HAM serta memiliki tugas dan fungsi untuk melakukan pembinaan serta pelaksanaan hukuman terhadap para narapidana dan anak didik pemasyarakatan yang ada di dalamnya. Konsep pemasyarakatan sendiri pertama kali digagas oleh menteri kehakiman Sahardjo pada tahun 1962 yang menyatakan bahwa tugas jawatan kepenjaraan bukan hanya melaksanakan hukuman, melainkan juga tugas yang jauh lebih berat yakni mengembalikan orang-orang yang dijatuhi hukuman atau pidana ke dalam lingkungan masyarakat agar kembali diterima dalam proses pemasyarakatan di lingkungan nya masing-masing (Irwan \& Widiarty, 2008).

Pengaturan mengenai proses pembinaan yang dilakukan di dalam Lembaga Pemasyarakatan di Indonesia diatur dan tertuang dalam Undang-Undang Republik Indonesia Nomor 12 Tahun 1995 tentang Pemasyarakatan, dimana dalam UndangUndang tersebut dalam pasal 5 dijelaskan tentang sistem pembinaan di dalam lembaga pemasyarakatan yang menentukan bahwa sistem Pembinaan pemasyarakatan dilaksanakan berdasarkan asas:

a. Pengayoman

b. Persamaan perlakuan dan pelayanan

c. Pendidikan

d. Pembimbingan

e. Penghormatan harkat dan martabat manusia

f. Kehilangan kemerdekaan merupakan satusatunya penderitaan dan

g. Terjamin nya hak untuk tetap berhubungan dengan keluarga dan orang-orang tertentu.

Selanjutnya segala jenis tata urusan dan juga aturan tentang Lembaga Pemasyarakatan diatur sepenuhnya di dalam Undang-Undang Nomor 12 Tahun 1995 tentang Pemasyarakatan segala jenis tatanan mengenai arah dan batas serta cara pembinaan warga binaan pemasyarakatan berdasarkan pancasila yang dilaksanakan secara terpadu antara pembina, yang dibina dan masyarakat untuk untuk meningkatkan kualitas warga binaan pemasyarakatan agar menyadari kesalahan, memperbaiki diri, dan tidak mengulangi tindak pidana sehingga dapat diterima kembali oleh lingkungan masyarakat, dapat aktif berperan dalam pembangunan, dan dapat hidup secara wajar sebagai warga yang baik dan bertanggungjawab. 
Lembaga pemasyarakatan Kelas IIA Denpasar merupakan salah satu Lembaga Pemasyarakatan terkemuka di Provinsi Bali dengan visi menjadi pusat unggulan Lembaga Pemasyarakatan dan pengembangan kegiatan pembinaan kemandirian keterampilan bagi warga binaan pemasyarakatan yang berbasis pada moral, sosial dan kemandirian. Misi membina anak didik warga binaan Pemasyarakatan di bidang kegiatan kerja yang memiliki keunggulan dalam keterampilan dan teknologi melalui pembinaan, pelatihan serta pembimbingan kerja, sehingga diharapkan menjadi manusia bermoral pancasila yang bersosialisasi dengan masyarakat, dengan berprinsip pada kemandirian. Selanjutnya Lembaga Pemasyarakatan ini lebih dikenal dengan Lapas Kerobokan. Sebelum menjadi Lembaga Pemasyarakatan Kelas IIA Denpasar, Lembaga Pemasyarakan ini telah mengalami beberapa kali relokasi. Pada mulanya, lembaga pemasyarakatan ini terletak di daerah Pekambingan Denpasar dengan kapasitas penghuni yang lebih sedikit, dan didirikan oleh pemerintah kolonial Belanda pada tahun 1916. Seiring berjalannya waktu, daerah pekambingan dianggap kurang sesuai karena berkembang menjadi daerah padat penduduk sedangkan dibutuhkan kapasitas penjara yang lebih besar maka Penjara Denpasar kemudian dipindahkan ke daerah Kerobokan yang terletak di wilayah Kabupaten Badung dan diresmikan pada tahun 1983. Kemudian bekas lokasi penjara Denpasar itu dibangun pusat pertokoan yang diresmikan oleh mantan Gubernur Bali Ida Bagus Mantra tahun 1986. Wilayah Kerobokan di Kabupaten Badung kemudian dipilih sebagai lokasi baru Lapas Denpasar dengan luas tanah 2,5 hektar dengan Pertimbangan wilayah ini masih dekat dengan Kota Denpasar.

Lembaga Pemasyarakatan kelas II A Denpasar yang dihuni oleh 1684 orang narapidana pada dasarnya memiliki berbagai kegiatan yang harus dan wajib dilaksanakan oleh semua penghuni Lapas. Kegiatan-kegiatan yang dilakukan tersebut diklasifikasikan sesuai kedalam kelompok umur masing-masing penghuni yaitu kegiatan yang dilaksanakan oleh penghuni anak, kegiatan yang dilaksanakan oleh penghuni dewasa, serta kegiatan yang dilaksanakan oleh penghuni yang sudah lanjut usia. kegiatan yang dilaksanakan oleh Lembaga Pemasyarakatan terhadap para narapidana dibagi menjadi dua jenis kegiatan pembinaan yaitu pembinaan secara kepribadian serta pembinaan kemandirian.

Berdasarkan hasil wawancara yang dilaksanakan tanggal 12 Februari 2019 dengan narasumber Ayu Lasmiyanthi selaku Kepala urusan umum di Lembaga Pemasyarakatan terkait jadwal kegiatan terstruktur yang dilaksanakan oleh seluruh narapidana di Lapas Kelas II A Denpasar, bahwa seluruh kegiatan yang dilaksanakan oleh para narapidana diawasi secara ketat oleh para petugas Lembaga Pemasyarakatan dengan rincian jadwal kegiatan yang dibuat dan dilaksanakan setiap harinya oleh para narapidana. Jadwal kegiatan yang dilaksanakan para narapidana telah diatur sedemikian rupa dengan rincian kegiatan yakni, Pukul 07.30 pagi para narapidana sudah keluar dari wisma masing-masing dan bersiap melakukan kebersihan lingkungan atau yang biasa disebut dengan korvei serta dilanjutkan dengan sarapan pagi. Kemudian dilanjutkan pukul 08.15 pagi dilaksanakan kegiatan kesegaran jasmani yang pelaksanaan nya digilir sesuai dengan wisma masing-masing. Pada Pukul 09.00 pagi para narapidana sudah bisa menerima kunjungan dari kerabat serta keluarga mereka yang mengunjungi ke dalam Lembaga Pemasyarakatan, namun jika narapidana tidak mendapat kunjungan dari kerabat ataupun keluarga nya maka kegiatan akan terus berlanjut ke pembekalan skill atau keahlian yang semua kegiatan nya disesuaikan dengan minat bakat masing-masing narapidana dan dilaksanakan hingga pukul 12.00 siang, setelah itu maka para narapidana akan diberikan waktu istirahat siang serta melakukan apel siang hingga pukul 13.00. Setelah istirahat selesai, maka kegiatan pembinaan skill dan keahlian akan berlanjut hingga pukul 17.00 sore sebelum akhirnya para narapidana akan kembali melaksanakan kegiatan apel sore dan kembali ke dalam sel masing-masing.

Jenis kegiatan kemandirian yang dilaksanakan setiap harinya oleh para narapidana bervariasi, mulai dari kegiatan kemandirian menyablon, melukis, kemandirian salon, kemandirian peternakan, kegiatan kemandirian bakery, kegiatan kemandirian perak, berkebun, pengolahan barang bekas kemandirian tata boga, budidaya jamur, kegiatan kemandirian pertamanan, kemandirian bengkel hingga desain grafis serta masih banyak kegiatan kemandirian yang bisa dilakukan oleh para warga binaan Lembaga Pemasyarakatan kelas IIA Denpasar yang mana nantinya hasil pembinaan kemandirian ini akan berjalan secara berkesinambungan karena beberapa hasil karya kemandirian warga binaan tersebut sudah dilakukan kerjasama dengan pihak dinas terkait yang berhubungan dan menaungi hasil karya para warga binaan Lembaga Pemasyarakatan. Sebagai contoh yaitu pembinaan kemandirian Pertanian dan 
perkebunan dilakukan kerjasama dengan dinas pertanian dan perkebunan kabupaten Badung sehingga hasil pembinaan kemandirian dari narapidana di bidang pertanian dan perkebunan dapat langsung disalurkan ke dinas terkait untuk kemudian bisa dikelola dengan baik dan memberikan manfaat untuk masyarakat luas dan untuk warga binaan itu sendiri.

Pembinaan yang dilaksanakan terhadap para narapidana disesuaikan dengan masingmasing usia narapidana antara narapidana anak, dewasa dan juga lansia. Perbedaan pelaksanaan pembinaan terhadap para narapidana ini dilakukan karena masing-masing narapidana memiliki tingkat kebutuhan yang berbeda hingga akhirnya harus dilakukan perbedaan terhadap jenis-jenis kegiatan yang dilakukan terutama kegiatan yang diberikan untuk para narapidana yang sudah lanjut usia yang memang perlu perhatian dan perlakuan lebih khusus daripada narapidana lain nya.

Kegiatan yang di khususkan untuk para narapidana yang sudah lanjut usia diantaranya adalah lebih mengedepankan kegiatan pembinaan psikis dan mental para narapidana lanjut usia sehingga kegiatan pembinaan lebih ringan dibanding kegiatan pembinaan yang diberikan kepada narapidana yang masih tergolong dewasa. Dengan pembinaan psikis dan mental para narapidna yang sudah lanjut usia tersebut maka akan melatih tingkat kemandirian dan rasa percaya diri selama menjalani proses pembinaan di Lembaga Pemasyarakatan bagi para narapidana lanjut usia. Selain itu, kegiatan rohani juga menjadi salah satu kegiatan wajib para narapidana lanjut usia yang dilakukan setiap harinya serta pemisahan blok hunian para narapidana lanjut usia juga menjadi salah satu perlakuan khusus yang diberikan kepada narapidana lanjut usia yang memang perlu mendapat perlakuan dan perhatian khusus.

\section{Upaya Penyelesaian Kendala, Dalam Melakukan Pembinaan Terhadap Narapidana Lanjut Usia di Lembaga Pemasyarakatan Kelas II A Denpasar}

Salah satu faktor penting yang menghambat proses pembinaan terhadap narapidana lanjut usia berdasarkan hasil wawancara di Lembaga Pemasyarakatan adalah kondisi fisik dari para narapidana lanjut usia yang sudah tidak memungkinkan lagi untuk melaksanakan kegiatan-kegiatan aktif dan rutin yang diberikan kepada narapidana di Lembaga Pemasyarakatan. Terkadang ada pula narapidana lanjut usia yang sifat dan karakteristiknya kembali memasuki fase anakanak dimana para narapidana lanjut usia memerlukan perhatian lebih dari pihak Lembaga Pemasyarakatan itu sendiri maupun keluarga dari narapidana lanjut usia.

Lembaga Pemasyarakatan, sebagaiamana telah diterangkan dalam pembahasan sebelumnya selain sebagai lembaga yang merupakan tahap akhir dari sistem peradilan pidana juga berfungsi sebagai lembaga yang melakukan pembinanaan, agar setelah menjalani masa hukumannya, para narapidana dapat kembali bermasyarakat. Pembinaan narapidana tidak semata untuk memberikan efek jera, namun juga membina agar menjadi individu yang lebih baik di masyarakat.

Pembinaan narapidana di dalam Lembaga Pemasyarakatan dilaksanakan dengan metode atau cara sebagai berikut (Supriyono, 2012):

a. Pembinaan interaksi langsung yang bersifat kekeluargaaan antara petugas pembina dan narapidana.

b. Pembinaan yang bersifat persuasif yang ditujukan untuk memperbaiki pola tingkah laku melalui contoh-contoh dan keteladanan.

c. Menempatkan narapidana sebagai manusia yang memiliki potensi dan harga diri dengan hak dan kewajiban yang sama dengan manusia lainnya.

d. Pembinaan dilaksanakan berencana, terus menerus dan sistematis

e. Pendekatan dilakukan secara individual dan kelompok.

Persoalan-persoalan yang ditemukan di lapangan dalam penelitian ini, yakni banyak terdapatnya kendala dalam membina Narapidana Lanjut Usia dimana telah diterangkan dalam sub bab sebelumnya, maka Narapidana lanjut usia memerlukan pembinaan lebih khusus daripada tahanan dewasa lainnya, dikarenakan oleh kondisi fisik atau jasmani serta rohani atau psikologisnya. Dalam upaya penanganan kondisi fisik atau jasmani narapidana lanjut usia, Lembaga Pemasyarakatan Kelas IIA Denpasar memberikan pelayanan kesehatan yang lebih intensif dan rutin secara berkala.

Terhadap kondisi rohani atau psikologis narapidana lanjut usia yang cenderung lebih mudah merasa tertekan seperti lanjut usia pada umumnya, juga perlu diberikan penanganan lebih. Upaya penanganan yang dilakukan oleh Lembaga Pemasyarakatan Kelas IIA Denpasar 
dalam hal ini adalah memberikan terapi mental seperti terapi ketawa serta mengadakan sharing atau diskusi, sehingga dapat mengurangi tekanan mental yang dihadapi oleh narapidana lanjut usia.

\section{Simpulan}

Lembaga pemasyarakatan sebagai sebuah lembaga yang berdiri dibawah naungan kementerian Hukum dan HAM memiliki tugas pokok dan fungsi untuk melakukan pembinaan terhadap para narapidana di dalam Lembaga Pemasyarakatan. Segala jenis aturan yang berhubungan dengan Lembaga Pemasyarakatan diatur dalam Undang-Undang Nomor 12 Tahun 1995 tentang pemasyarakatan dimana segala ketentuan tata aturan di dalam Lembaga Pemasyarakatan diatur di dalamnya. Lembaga Pemasyarakatan Kelas II A Denpasar yang berkedudukan di wilayah Kerobokan Kabupaten Badung merupakan Lembaga Pemasyarakatan terbesar di Provinsi Bali dengan kapasitas 1000 orang penghuni di dalamnya. Sistem pembinaan yang dilakukan oleh Lembaga Pemasyarakatan ini memberikan pembinaan berupa pembinaan kemandirian dan pembinaan kepribadian yag dilaksanakan setiap hari nya kepada para narapidana.

Dengan total jumlah penghuni Lapas mencapai 1684 orang, dengan klasifikasi 7 orang narapidana anak, 1663 orang tergolong narapidana dewasa, dan 14 orang narapidana yang sudah lanjut usia. Faktor usia merupakan faktor penting dan penentu pembinaan seperti apa yang bisa diberikan kepada narapidana sesuai dengan golongan umurnya. Penghuni lanjut usia merupakan yang paling diperlukan perhatian dan fokus lebih di dalam melakukan pembinaan, karena kendala yang dihadapi dalam proses pembinaan yang dilakukan terhadap para narapidana lanjut usia adalah kondisi kesehatan yang rentan terkena penyakit dan juga kondisi fisik yang sudah tidak lagi kuat untuk menjalani proses pembinaan di dalam Lembaga Pemasyarakatan.

\section{Daftar Pustaka}

Barus, B. J. P., \& Biafri, V. sylvia. (2020). Pembinaan Kemandirian Terhadap Narapidana Lanjut Usia Di Lembaga Pemasyarakatan Kelas I Medan. Nusantara: Jurnal Ilmu Pengetahuan Sosial, 7(1). Retrieved from http://dx.doi.org/10.31604/ jips.v7i1.2020.135-148

Beliferdo, A., Darmadi, A. A. N. Y., \& Tjatrayasa, I. M. (2013). Pembinaan Narapidana Lanjut Usia Di LP Karangasem. Kertha Wicara, 1 (5). Retrieved from https://ojs.unud.ac.id/ index.php/kerthawicara/article/ view/7157/5416

Efendi, J., \& Ibrahim, J. (2016). Metode Penelitian Hukum Normatif dan Empiris. Depok: Prenadamedia. Retrieved from https:// books.google.co.id/books? $\mathrm{id}=5 \mathrm{OZeDwAAQBAJ} \& \mathrm{pg}=\mathrm{PR} 4 \& \operatorname{lpg}=\mathrm{PR} 4$ $\& d q=$ Johny + Ibrahim $,+2016,+$ Metode + Pene litian+Hukum+Normatif + dan+Empiris, + De pok, + Prenadamedia + Group.\&source $=$ bl\&ot $\mathrm{s}=67 \mathrm{a} 5 \mathrm{f} 7 \mathrm{z}-$

$\mathrm{jR \& sig=ACfU3U1ySfuoCRH \_ 1fr39Z5gNM}$ UDeJ-

CWQ\&hl $=\mathrm{id} \&$ sa $=X \& v e d=2$ ahUKEwjC $4 n$ a8KrqAhXDe30KHc5ZDQMQ6AEwAX ECAoQAQ\# $\mathrm{v}=$ onepage \&q $=$ Johny Ibrahim\%2C 2016\%2C Metode Penelitian Hukum Normatif dan Empiris\%2C Depok\%2C Prenadamedia Group.\&f=false

Irwan, P. P., \& Widiarty, W. S. (2008). Pembaharuan Pemikiran Dr. Sahardjo Mengenai Pemasyarakatan Narapidana. Jakarta: Indiholl. Retrieved from https:// opac.perpusnas.go.id/DetailOpac.aspx? $\mathrm{id}=498894$

Supriyono, B. (2012). Peningkatan Kinerja Pembinaan Lembaga Pemasyarakatan Terbuka Kelas IIB Nusakambangan. Semarang: Kementerian Hukum dan Hak Asasi Manusia Jawa Tengah.

Tumpa, H. A. (2009). Peluang dan Tantangan Eksistensi Pengadilan HAM di Indonesia. Jakarta: Kencana Prenada Media Group.

Yusuf, A. M. (2014). Metode Penelitian Kuantitatif, Kualitatif dan Penelitian Gabungan. Jakarta: Kencana Prenada Media Group. Retrieved from https://books.google.co.id/ books?id=RnA-

DwAAQBAJ\&printsec $=$ frontcover\&hl $=\mathrm{id} \#$ $\mathrm{v}=$ onepage \&q $\& \mathrm{f}=$ false 